\title{
Simultaneous removal of lead and copper from synthetic water by electrocoagulation and techno-economic evaluation: optimization through response surface methodology
}

\author{
A. K. Varma ${ }^{1}$, A. Chouhan ${ }^{2}$, R. Shankar ${ }^{3}$, P. Mondal $^{4}$, A.K. Rathore ${ }^{5}$, L.S. Thakur ${ }^{2} *$ \\ ${ }^{I}$ Department of Chemical Engineering, Assam Energy Institute (A centre of RGIPT, Jais, Amethi) Sivasagar, Assam, INDIA \\ ${ }^{2}$ Department of Chemical Engineering Ujjain Engineering College Ujjain, Madhya Pradesh, INDIA \\ ${ }^{3}$ Department of Chemical Engineering, Madan Mohan Malviya University of Technology, Gorakhpur, Uttar Pradesh, INDIA \\ ${ }^{4}$ Department of Chemical Engineering, Indian Institute of Technology Roorkee, Roorkee, Uttarakhand, INDIA \\ ${ }^{5}$ Department of Chemical Engineering, Harcourt Butler Technical University, Kanpur, Uttar Pradesh, INDIA \\ "Corresponding Author: e-mail: lokendrast@ rediffmail.com, Tel +91-734-2511912, Fax.+91-734-2511912 \\ https://orcid.org/0000-0002-8407-4503 (L.S.Thakur)
}

\begin{abstract}
In the present study, the electrocoagulation process using iron electrodes was used to treat synthetic water containing lead and copper. Box-Behnken design of response surface methodology was applied to optimize the process variables namely initial $\mathrm{pH}$, current density and treatment time along with operating cost. At optimum conditions (initial pH: 5 , current density: $50 \mathrm{~A} / \mathrm{m}^{2}$, treatment time: $40 \mathrm{~min}$ ), the model predicted value for removal of lead and copper was found as $102.81 \%$ and $99.75 \%$, respectively with an operating cost of $0.481 \mathrm{USD} / \mathrm{m}^{3}$. Whereas, the actual or experimental values of lead and copper removal were found as $99.98 \%$ and $99.88 \%$ as well as operating cost of $0.476 \mathrm{USD} / \mathrm{m}^{3}$, which signifies a good closeness between the model predicted values and actual values. The concentration of lead and copper in treated water was found below the permissible limits as per CPCB norms for industrial discharge.
\end{abstract}

Keywords: Electrocoagulation, lead, copper, operating cost, Box-Behnken design.

DOI: http://dx.doi.org/10.4314/ijest.v13i1.9S

Cite this article as:

Varma A. K., Chouhan A., Shankar R., Mondal P., Rathore A.K., Thakur L.S. 2021. Simultaneous removal of lead and copper from synthetic water by electrocoagulation and techno-economic evaluation: optimization through response surface methodology, International Journal of Engineering, Science and Technology, Vol. 13, No. 1, pp. 61-68. doi: 10.4314/ijest.v13i1.9S

Received: December 1, 2019; Accepted: February 5, 2021; Final acceptance in revised form: March 31, 2021

This paper was earlier presented at the International Conference on Energy, Environment \& Material Sciences (ICE2M), 1-3 December 2019 and substantially improved for this Special Issue. Guest Editor: Dr. Sri Niwas Singh, Professor (HAG), Department of Electrical Engineering, Indian Institute of Technology Kanpur, 208016 (U.P.) India, former Vice-Chancellor, Madan Mohan Malviya University of Technology Gorakhpur (April 2017 to July 2020).

\section{Introduction}

Due to exponential increase in number of industries and human colonization in all parts of the world, ecosystem has been devastatingly affected by release of toxic heavy metals in the water bodies. Even very less amount of toxic heavy metal can lethally contaminate the water bodies, so the risk of impact of heavy metals cannot be ignored any more. Removal of toxic heavy metal from water has become a topic of major concern in all parts of the world due to strict environmental laws (Yetilmezsoy $e t$ al., 2009). 
Lead has been reported as one of the most hazardous heavy metals (Yetilmezsoy et al., 2009). It enters into the environment through natural and anthropogenic process such as earth crust, volcanic activities, sulfide ore smelting, mining and fossil fuel combustion (Rajput et al., 2016). Long term exposure of lead can be responsible for the general metabolic poison, blood and brain disorder (Mohod and Dhote, 2013). Copper is an essential element for living beings. Industrial effluents of pulp, paperboard mills, metal cleaning, plating baths etc are the major source of copper contamination in water (Boujelben et al., 2009). Copper toxicity leads injury to red blood cells, lungs and damage the pancreatic and liver functions (Bailey et al., 1999). There are many industries such as leather, paper and pulp, smelting, electrical, mining and electroplating in which both lead and copper are found in effluent (Iqbal and Khera, 2015).

Among the various available technologies such as chemical precipitation, ion exchange, membrane separation etc for the treatment of wastewater, electrocoagulation (EC) process is the most efficient and cost effective technique (Adhoum et al., 2004; Can et al., 2006). The process of electrocoagulation involves the formation of coagulant inside the cell as direct current is passed in cell. Iron anode dissolves and releases metal ions in the solution simultaneously hydrogen gas is evolved at cathode which thereby creates froth (Adhoum et al., 2004). This froth make the contaminants float on the upper surface (Fu and Wang, 2011). Oxidation takes place at anode, whereas, reduction occurs at cathode. Removal of contaminants may occur due to adsorption, charge neutralization, co-precipitation, sweep coagulation, sedimentation or floatation (Thakur and Mondal, 2016). Main reactions occur in case of iron electrodes are as follows (Bazrafshan et al., 2011).

At anode:

At cathode:

$$
\mathrm{Fe}(\mathrm{s}) \rightarrow \mathrm{Fe}^{3+}(\mathrm{aq})+3 \mathrm{e}^{-}(\mathrm{aq})
$$

$2 \mathrm{H}_{2} \mathrm{O}(\mathrm{I})+2 \mathrm{e}^{-}(\mathrm{aq}) \rightarrow \mathrm{H}_{2}(\mathrm{~g})+2 \mathrm{OH}^{-}(\mathrm{aq})$

$\mathrm{Fe}^{3+}$ and $\mathrm{OH}^{-}$ions gets hydrolysed in solution and form ferric hydroxide:

$$
\mathrm{Fe}^{3+}+3 \mathrm{OH}^{-} \rightarrow \mathrm{Fe}(\mathrm{OH})_{3}
$$

There are many literatures available on the removal of lead and copper from wastewater (Mansoorian et al., 2014; Gatsios et al., 2015; Bhagawan et al., 2014). However, there is limited research work found on the techno economic assessment of the lead/copper removal by electrocoagulation process (Bhagawan et al., 2014). Nevertheless, no literature is available on simultaneous removal of lead and copper as well as their techno economic evaluation by electrocoagulation using Response Surface Methodology (RSM). RSM is an intelligent technique in terms of mathematical and statistical analysis used for experimental design, building of model and to optimize the process parameters. RSM also reveals the relationship between the input factors and response (Thakur and Mondal, 2016). The present research focused on a) To optimize the process parameters such as current density, initial $\mathrm{pH}$ and treatment time for simultaneous treatment of lead and copper from synthetic water coupled with the operating cost through electrocoagulation process by using Box-Behnken Design (BBD), b) To build input-output model for EC process, c) To affirm the established model.

\section{Materials and Methods}

2.1 Material: All the chemicals were of analytical grade and solution was prepared with distilled water. 1N HCL and 1N NaOH solution were used to attain the desired $\mathrm{pH}$ of the solution. All electrocoagulation experiments were done in a batch reactor, which was made of Perspex with dimension of $15 \mathrm{~cm} \times 10 \mathrm{~cm} \times 12 \mathrm{~cm}$. Iron $(\mathrm{Fe})$ plates $(8 \mathrm{~cm} \times 8 \mathrm{~cm})$ were used as anode and cathode. Electrodes were coupled to DC power supply (0-10A and 0-30V). Anode and cathode was kept constant at $1 \mathrm{~cm}$ apart for all the experiments.

2.2 Methods: Before start of experiment, electrodes were cleaned using sand paper, dilute nitric acid and finally with distilled water, after that dried in a hot air oven and weighted. By the end of each experiment, electrodes were cleaned with tap water in order to remove any solid residual particle from electrode surface. The electrodes were again dried and weighted. The experimental solution is comprised of definite concentration of $10 \mathrm{mg} / \mathrm{L}$ of lead and $40 \mathrm{mg} / \mathrm{L}$ of copper and it was analysed under various experimental conditions with stirring done at 400 RPM by magnetic stirrer. Fig. 1 represents the setup of electrocoagulation process. Sodium chloride $(1 \mathrm{gm} / \mathrm{l})$ was added into the solution to increase the electrical conductivity. At the end of each experiment, final sample was filtered with 0.45 micron Whatman filter to analyse the concentration of lead and copper by using Atomic Absorption Spectrophotometer (AAS, Shimadzu, model-AA-6300). Removal efficiency of lead and copper was computed by the following Equation:

$$
\text { Removal efficiency }(\%)=\left(\mathrm{C}_{\mathrm{i}}-\mathrm{C}_{\mathrm{f}}\right) / \mathrm{C}_{\mathrm{i}} \times 100
$$

Where $C_{i}$ and $C_{f}$ are initial concentration and final concentration of contaminants in solution, respectively. For the operating cost, only the cost of electrode \& electricity was considered (Equation 5) [10].

$$
\text { Operating cost }=\mathrm{a} \times \mathrm{C}_{\text {electrode }}+\mathrm{b} \times \mathrm{C}_{\text {energy }}
$$

Where, $\mathrm{C}_{\text {electrode }}$ is electrode consumption used in the treatment of lead and copper $\left(\mathrm{kg} / \mathrm{m}^{3}\right), \mathrm{C}_{\text {energy }}$ is the electrical energy used in the treatment of lead and copper $\left(\mathrm{Kwh} / \mathrm{m}^{3}\right)$, a is wholesale electrode material price $=0.62 \mathrm{USD} / \mathrm{kg}(\mathrm{Web}$ link 1$)$ and $\mathrm{b}$ is the industrial electricity price $=0.11 \mathrm{USD} / \mathrm{kwh}($ Web link 2).

Energy consume in EC process was computed by Equation 6:

$$
\text { Energy consumption }\left(\mathrm{Kwh} / \mathrm{m}^{3}\right)=(\text { voltage } \times \text { current } \times \text { runtime }) /(\text { Working volume of reactor })
$$


The electrode material cost was considered in terms of weight loss during the experiment by subtracting the weight of anode electrode before and after electrocoagulation process (Thakur and Mondal, 2016).

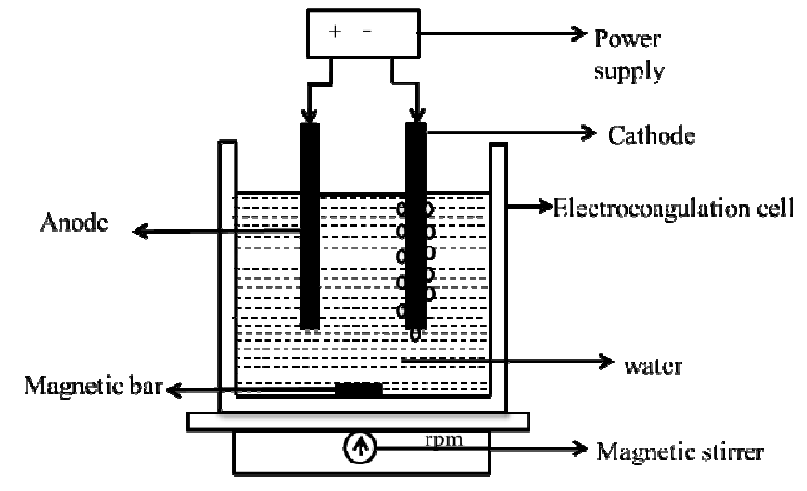

Fig. 1 Experimental setup for electrocoagulation process

2.3 Box-Behnken Design: Box-Bhenken Design (BBD) is an independent quadratic design it does not comprise any embedded factorial design. BBD uses three level factors and establishes quadratic models. BBD is rotatable or nearly rotatable used three factors of each level to run (Ferreira et al., 2007). In the present work, three level BBD is applied to study the effect of process variables (A: initial $\mathrm{pH}, \mathrm{B}$ : current density, $\mathrm{C}$ : Treatment time) at three levels $(-1,0,+1)$ on the three responses $\left(\mathrm{Y}_{1}\right.$ : lead removal $(\%), \mathrm{Y}_{2}$ : copper removal $(\%)$ and $\mathrm{Y}_{3}$ : operating cost). To develop empirical model and to correlate the $\%$ removal of lead and copper as well as operating cost with the process variables, the data generated through 17 numbers of experiments mentioned in Table 1, have been processed using Design of expert software (DOE 7.0.0).

Table 1. Box Behnken Design

\begin{tabular}{|c|c|c|c|c|c|c|c|}
\hline $\begin{array}{c}\text { Run } \\
\text { no. }\end{array}$ & $\begin{array}{c}\text { Initi } \\
\text { al } \\
\text { pH }\end{array}$ & $\begin{array}{c}\text { Curre } \\
\text { nt } \\
\text { density } \\
\left(\mathbf{A} / \mathbf{m}^{2}\right)\end{array}$ & $\begin{array}{l}\text { Treat } \\
\text { ment } \\
\text { time } \\
(\text { min) }\end{array}$ & $\begin{array}{c}\text { Lead } \\
\text { remo } \\
\text { val } \\
(\%)\end{array}$ & $\begin{array}{l}\text { Coppe } \\
\text { r } \\
\text { remov } \\
\text { al }(\%)\end{array}$ & $\begin{array}{c}\text { Oper } \\
\text { ating } \\
\text { cost } \\
(\mathbf{U S D} / \\
\left.\mathbf{m}^{3}\right)\end{array}$ & $\begin{array}{c}\text { Fin } \\
\text { al } \\
\text { pH }\end{array}$ \\
\hline 1 & 5 & 30 & 25 & 85.88 & 75.01 & 0.171 & 6.9 \\
\hline 2 & 5 & 30 & 25 & 88.9 & 73.2 & 0.169 & 6.9 \\
\hline 3 & 5 & 50 & 45 & 99.99 & 99.99 & 0.545 & 7.0 \\
\hline 4 & 8 & 10 & 25 & 25.76 & 60.1 & 0.052 & 8.3 \\
\hline 5 & 2 & 50 & 25 & 57.11 & 80.8 & 0.293 & 5.4 \\
\hline 6 & 8 & 30 & 45 & 85.88 & 90.1 & 0.307 & 9.7 \\
\hline 7 & 5 & 10 & 5 & 9.89 & 22.01 & 0.010 & 5.2 \\
\hline 8 & 2 & 30 & 5 & 19.9 & 39.9 & 0.032 & 2.6 \\
\hline 9 & 5 & 10 & 45 & 43.45 & 68.2 & 0.094 & 5.4 \\
\hline 10 & 5 & 30 & 25 & 83.21 & 73.1 & 0.167 & 6.8 \\
\hline 11 & 5 & 50 & 5 & 30.11 & 84.1 & 0.060 & 5.3 \\
\hline 12 & 2 & 30 & 45 & 50.4 & 64.01 & 0.302 & 5.6 \\
\hline 13 & 5 & 30 & 25 & 86.56 & 75.5 & 0.166 & 6.9 \\
\hline 14 & 8 & 50 & 25 & 91.45 & 95.45 & 0.303 & 9.1 \\
\hline 15 & 2 & 10 & 25 & 21.3 & 29.01 & 0.051 & 3.2 \\
\hline 16 & 5 & 30 & 25 & 83.02 & 73.8 & 0.170 & 6.9 \\
\hline 17 & 8 & 30 & 5 & 24.12 & 49.9 & 0.033 & 8.4 \\
\hline
\end{tabular}




\section{Results and Discussion}

3.1 Development of Electrocoagulation Models: Using Design-Expert 7.0.0 software, all the responses such as linear, 2-factor interaction, quadratic and cubic models were analyzed and suggested lowest p-value for the quadratic model only. The $\mathrm{p}$-value was low for all the three models which signifies that minimum one of the variable in each model has significant effect on the response. The developed quadratic models given by Design of expert software are as follow:

Lead removal $\left(\mathbf{Y}_{1}\right)=-69.07+17.05 \times \mathrm{pH}+2.61 \times$ Current density $+2.60 \times$ Treatment time $+0.12 \times \mathrm{pH} \times$ Current density + $0.13 \times \mathrm{pH} \times$ Treatment time $+0.02 \times$ Current density $\times$ Treatment time $-2.07 \times \mathrm{pH}^{2}-0.044 \times$ Current density $^{2}-0.05 \times$ Treatment time ${ }^{2}$

Copper removal $\left(\mathbf{Y}_{2}\right)=-42.80+12.33 \times \mathrm{pH}+1.96 \times$ Current density $+1.70 \times$ Treatment time $-0.068 \times \mathrm{pH} \times$ Current density + $0.067 \times \mathrm{pH} \times$ Treatment time $-0.02 \times$ Current density $\times$ Treatment time $-0.85 \times \mathrm{pH}^{2}-2.3 \times 10^{-4} \times$ Current density $^{2}-0.014 \times$ Treatment time ${ }^{2}$

Operating cost $\left(\mathbf{Y}_{3}\right)=0.016+6.08 \times 10^{-4} \times \mathrm{pH}-1.37 \times 10^{-3} \times$ Current density $-7.8 \times 10^{-4} \times$ Treatment time $+3.62 \times 10^{-5} \times \mathrm{pH} \times$ Current density $+1.70 \times 10^{-5} \times \mathrm{pH} \times$ Treatment time $+2.5 \times 10^{-4} \times$ Current density $\times$ Treatment time $-1.42 \times 10^{-4} \times \mathrm{pH}^{2}+1.9 \times$ $10^{-5} \times$ Current density $^{2}+2.78 \times 10^{-6} \times$ Treatment time $^{2}$

In the present study, for all the three responses lead removal $\left(\mathrm{Y}_{1}\right)$, copper removal $\left(\mathrm{Y}_{2}\right)$ and operating cost $\left(\mathrm{Y}_{3}\right) \mathrm{R}^{2}$ value are recorded as 0.992, 0.997 and 0.999, respectively. The ANOVA results as listed in Table 2, whereas, the $\mathrm{p}$ value is $<0.0001$. The difference between predicted $\mathrm{R}^{2}$ and adjusted $\mathrm{R}^{2}$ for all three models are also in acceptable range $(<0.2)$ and the adequate precisions are also high (29.88-165.19). Thus, it is concluded that the quadratic models correlating the three responses with process parameters are appropriate.

Table 2. Anova results for lead, copper removal and operating cost

\begin{tabular}{|c|c|c|c|c|c|c|}
\hline Response & \multicolumn{2}{|c|}{ Lead removal $\left(\mathbf{Y}_{1}\right)$} & \multicolumn{2}{|c|}{ Copper removal $\left(\mathbf{Y}_{2}\right)$} & \multicolumn{2}{|c|}{ Operating cost $\left(\mathbf{Y}_{3}\right)$} \\
\hline Source & p-value & Remark & p-value & Remark & p-value & Remark \\
\hline Model & $<0.0001$ & Significant & $<0.0001$ & Significant & $<0.0001$ & Significant \\
\hline $\mathrm{A}$ & 0.0003 & & $<0.0001$ & & 0.1996 & \\
\hline B & $<0.0001$ & & $<0.0001$ & & $<0.0001$ & \\
\hline $\mathrm{C}$ & $<0.0001$ & & $<0.0001$ & & $<0.0001$ & \\
\hline $\mathrm{AB}$ & 0.008 & & 0.0026 & & 0.33 & \\
\hline $\mathrm{AC}$ & 0.0064 & & 0.0029 & & 0.6372 & \\
\hline $\mathrm{BC}$ & 0.003 & & $<0.0001$ & & $<0.0001$ & \\
\hline $\mathrm{A}^{2}$ & $<0.0001$ & & $<0.0001$ & & 0.5455 & \\
\hline $\mathrm{B}^{2}$ & $<0.0001$ & & 0.9191 & & 0.007 & \\
\hline $\mathrm{C}^{2}$ & $<0.0001$ & & 0.0004 & & 0.5991 & \\
\hline Lack of Fit & 0.0752 & Not significant & 0.0746 & Not significant & 0.0666 & Not significant \\
\hline & \multicolumn{2}{|c|}{$\begin{array}{l}\left.\mathrm{R}^{2}=0.992, \mathrm{R}^{2} \text { (pred. }\right)=0.904, \\
\mathrm{R}^{2} \text { (adj.) }=0.983, \text { A. } \mathrm{P} .= \\
29.88\end{array}$} & \multicolumn{2}{|c|}{$\begin{array}{l}\mathrm{R}^{2}=0.997, \\
\left.\mathrm{R}^{2} \text { (pred. }\right)=0.961, \mathrm{R}^{2} \text { (adj.) }= \\
0.993, \\
\text { A. P. }=55.73\end{array}$} & \multicolumn{2}{|c|}{$\begin{array}{l}\mathrm{R}^{2}=0.999, \mathrm{R}^{2} \text { (pred.) }=0.995 \\
\mathrm{R}^{2}(\text { adj. })=0.999, \text { A. P. = 65.19 }\end{array}$} \\
\hline
\end{tabular}

3.2 Analysis of Response Surfaces: Data generated through DOE are applied to plot the Fig.2 (a), (b) and (c) as well as also used to describe the effect of $\mathrm{pH}$, current density and treatment time, respectively on removal efficiency of lead and copper and operating cost. It is display from Fig.2 (a) that the percentage removal of lead raises from $60.97 \%$ at initial $\mathrm{pH} 2$ and complete removal is found at $\mathrm{pH}$ of 5 and above. This observation can be explained on the basis of the solution phase chemistry of the lead species and surface chemistry of the coagulant generated in situ. In the aqueous solution $\mathrm{Pb}(\mathrm{II})$ may exists in from of $\mathrm{Pb}^{2+}, \mathrm{PbOH}^{+}, \mathrm{PbO}_{2}(\mathrm{~s})$, $\mathrm{HPb} \mathrm{O}_{2}^{-}$. At lower $\mathrm{pH}$, the $\mathrm{Pb}(\mathrm{II})$ predominately present in positive charge species and iron (coagulant generated in situ) is also present in positive charge species $\left(\mathrm{Fe}^{2+} \& \mathrm{Fe}^{3+}\right.$ ) (Takeno 2005) and hence, due to charge repulsion these condition is not favor for the chemisorption of $\mathrm{Pb}$ (II), in spite of that $60.97 \%$ removal is observed at initial $\mathrm{pH} 2$. It is noticed that within 5 min of treatment time along with current density of $30 \mathrm{~A} / \mathrm{m}^{2}$, the solution $\mathrm{pH}$ increases from 2 to 2.6 (Run No. 8 in Table 2) and after 45 min it reached upto 5.6 (Run No. 12 in Table 2). Similarly, at treatment time of $25 \mathrm{~min}$, initial solution pH increases from 5 to 6.9 at 30 $\mathrm{A} / \mathrm{m}^{2}$ current density (Run no.1 in Table 2). These increase in solution $\mathrm{pH}$ may also play a role in removal. The iron hydroxide is produced in situ due to the dissociation of iron electrode during the electrocoagulation process. Several monomeric and polymeric species of iron having +ve, -ve and natural charges such as $\mathrm{HFeO}_{2(\mathrm{aq})}, \mathrm{Fe} O_{2}^{-}, \mathrm{FeO}_{(\mathrm{aq})}, \mathrm{Fe}^{2+}, \mathrm{Fe}^{3+}, \mathrm{FeOH}^{+}, \mathrm{FeOH}^{2+}, \mathrm{HFe}_{2}^{-}, \mathrm{FeO}^{+}$, $\mathrm{FeO}, \mathrm{Fe}_{2} \mathrm{O}_{3}, \mathrm{Fe}_{3} \mathrm{O}_{4}, \mathrm{Fe}(\mathrm{OH})_{2}^{+}, \mathrm{Fe}(\mathrm{OH})_{2}, \mathrm{Fe}(\mathrm{OH})_{2}^{+}, \mathrm{Fe}(\mathrm{OH})_{3}^{-}, \mathrm{Fe}(\mathrm{OH})_{4}^{-}, \mathrm{Fe}(\mathrm{OH})_{2}, \mathrm{Fe}(\mathrm{OH})_{2}^{4+}, \mathrm{Fe}(\mathrm{OH})_{2}^{5+}, \mathrm{FeOH}{ }^{2+}$ etc are formed during electrocoagulation (Takeno 2005; Kobya et al., 2003). Further the iron hydroxide species, as stated above may convert into amorphous $\mathrm{Fe}(\mathrm{OH})_{3(\mathrm{~s})}$ as per the complex precipitation kinetics (Lakshmanan et al., 2009). 

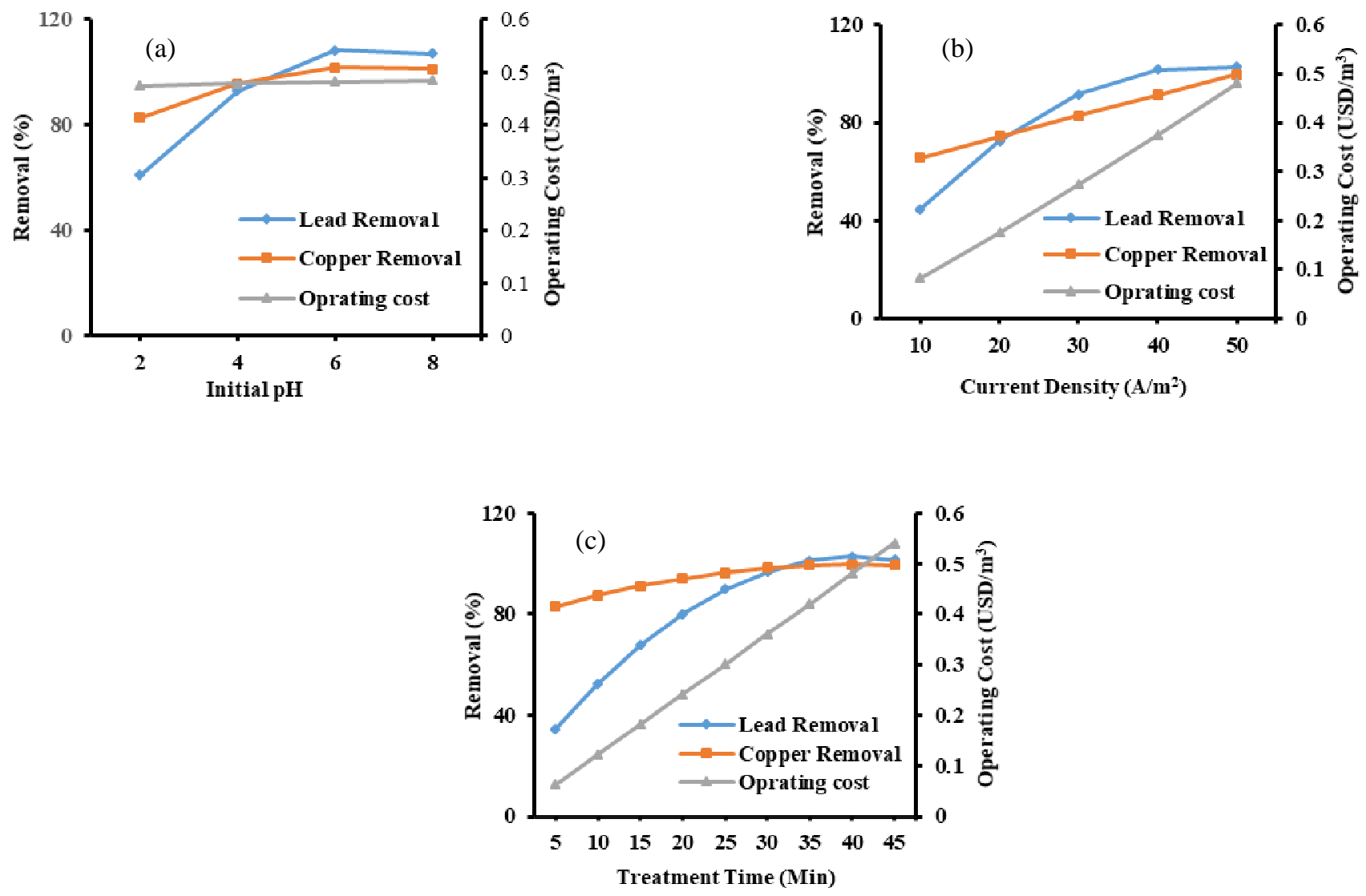

Fig. 2. Effect of process variables on $\mathrm{Y}_{1}, \mathrm{Y}_{2}$ and $\mathrm{Y}_{3}$ response on (a) Initial $\mathrm{pH}$, (b) Current density, (c) Treatment time.

These freshly formed amorphous $\mathrm{Fe}(\mathrm{OH})_{3}$ has minimum solubility, which results the formation of dense flocs, the dense flocs having a large surface area that provide entrapment of colloidal lead particles and hence the removal of lead takes place, which is known as sweep coagulation (Ghernaout and Ghernaout. 2012). Hence, at initial acidic and alkaline pH range, the elevation in solution $\mathrm{pH}$ with time and entrapment of lead in flocs (sweep coagulation) are accountable for lead removal. At initial $\mathrm{pH}$ of 2 , the copper removal of around $83.93 \%$ found and it increase with increase in initial $\mathrm{pH}$, total removal occur at $\mathrm{pH}$ of 5 . These removals can be explained on similar way as describe above for lead removal. In the aqueous solution, copper may exists in from of $\mathrm{Cu}^{2+}$, $\mathrm{Cu}(\mathrm{OH})_{2}, \mathrm{Cu}_{2} \mathrm{O}(\mathrm{s}), \mathrm{CuO}_{2}{ }^{(2-)}, \mathrm{HCuO}_{2}^{-}$(Takeno 2005). It is predominantly present in positive charge species up to $\mathrm{pH}$ of 9.5 and above this $\mathrm{pH}$ it present in negative charge species. Similarly, iron is also presents in positive charge species in these range, hence, chemisorption is less effective. Thus, sweep coagulation is also found accountable for high copper removal. Since, in the present study consider only electrode loss and power used thus the effect of initial $\mathrm{pH}$ is negligible on cost of operation.

Current density plays an vital role in the removal of lead and copper through EC process as it decides the rate of in situ coagulant generation (coagulant dose), which influences the removal efficiency. Current density is a measure of the amount of current passed through unit cross section area of the electrode. As per Faraday law, loss in weight of material is proportional to electricity passed in solution. It is clear that the increase in current density accelerate the liberation rate of iron coagulant, which finally helps to accelerate removal of lead and copper, thus removal \% of lead and copper increase with increase in current density. It is observed from Fig.2 (b) that at current density of $10 \mathrm{~A} / \mathrm{m}^{2}$, removal of lead and copper are obtained as $44.62 \%$ and $65.86 \%$, respectively under the above mention conditions. The lead and copper concentration in treated water are observed as $5.65 \mathrm{mg} / \mathrm{l}$ and $12.72 \mathrm{mg} / \mathrm{l}$, respectively, which are above their respective permissible limits according to Indian standards (lead: $0.1 \mathrm{mg} / \mathrm{l}$, copper: $3 \mathrm{mg} / \mathrm{l}$ ) (Web link 3). Further, at current density of $50 \mathrm{~A} / \mathrm{m}^{2}, \%$ removal of copper is found to be $99.75 \%$, while, complete removal of lead is found at same current density. The residual concentration of lead and copper are found as $0 \mathrm{mg} / \mathrm{l}$ and $0.1 \mathrm{mg} / \mathrm{l}$, respectively. With the increase in current density the operating cost of process also increases. It is ascertained from (Equation 5) that the operating cost is the sum of cost of electrode consumption during the treatment and electricity that used in the treatment. Therefore, as the current density increases the consumption of electrode dissolution as well as energy consumption also increases, consequently, the operating cost of electrocoagulation process increase.

The percentage removal of lead and copper both raises with rise in treatment time. Removal of $34.6 \%$ lead is attained in first 5 min operation and it improves further and get completely removed in $45 \mathrm{~min}$. It is also found that $82.97 \%$ of copper removal is attained in first $5 \mathrm{~min}$ of process and then rises gradually with treatment time. In treatment time of $40 \mathrm{~min}$ it reaches to its maximum removal of $99.75 \%$. Quick removal of copper is found as compare to lead. The concentration of both lead and copper in 
treated water found below the discharge limit of waste water according to Indian standard (lead: $0.1 \mathrm{mg} / \mathrm{l}$, copper: $3 \mathrm{mg} / \mathrm{l})$ (Web link 3 ). The operating cost of process is also increases with the increase in treatment time as the operating cost is proportional to treatment time (as per Equation 6). The sludge and scum produced during electrocoagulation process can also be sustainably utilized by using solidification techniques (Thakur et al., 2019). For the better explanation response surface parametric interaction for lead and copper removal as well as operating cost are shown in Fig. 3 (a), (b) \& (c), respectively which shows that lead and copper removals are responsive to variation of current density, $\mathrm{pH}$ and run time, respectively.

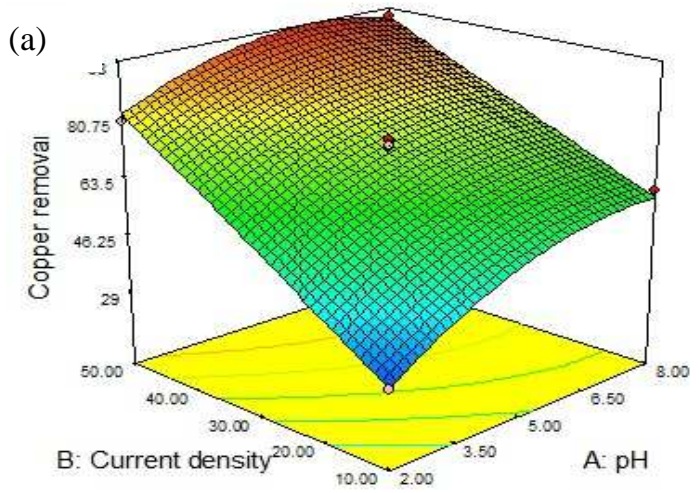

(b)

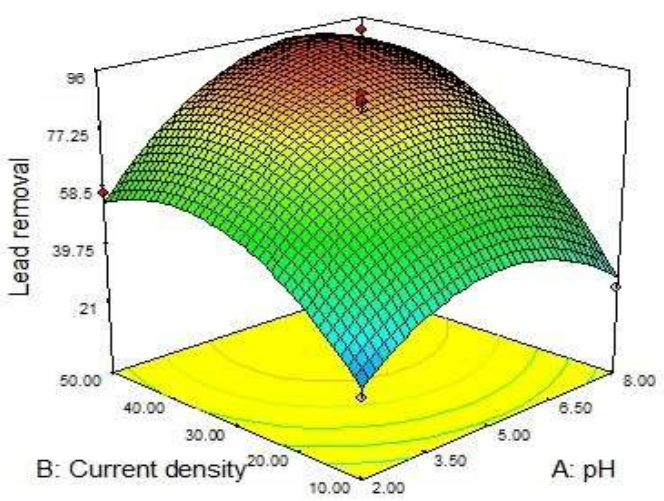

(c)

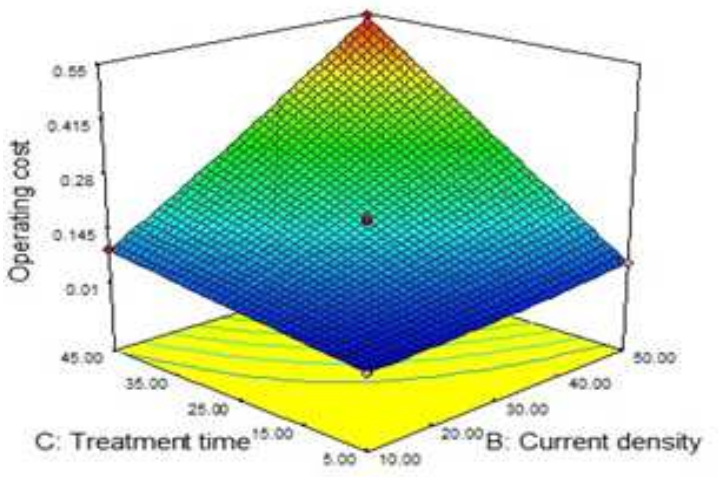

Fig. 3. 3D surface plots of lead removal, copper removal and operating cost with $\mathrm{pH}$ and current density $\left(\mathrm{A} / \mathrm{m}^{2}\right)(\mathrm{a}), \mathrm{pH}$ and current density $\left(\mathrm{A} / \mathrm{m}^{2}\right)(\mathrm{b})$, current density $\left(\mathrm{A} / \mathrm{m}^{2}\right)$ and treatment time $(\mathrm{min})(\mathrm{c})$, respectively.

3.3 Process Optimization: The optimum values of initial $\mathrm{pH}$, current density and treatment time for the removal of lead and copper coupled with the operating cost are evaluated by the developed models obtained from the experimental data. The optimum values are observed as initial pH: 5, current density: $50 \mathrm{~A} / \mathrm{m} 2$ and treatment time: 40 min according to BBD design. Under this optimum condition, removal of lead and copper are found as $102.81 \%$ and $99.75 \%$, respectively with an operating cost of $0.481 \mathrm{USD} / \mathrm{m}^{3}$ of treated water at the desirability of 0.999 . For the validation of model, the actual experiments were performed at these optimum conditions determined by Design Expert software, which found in good agreement with the model predicted value (lead removal: $99.98 \%$, copper removal: $99.88 \%$, operating cost: $\left.0.476 \mathrm{USD} / \mathrm{m}^{3}\right)$. Results revealed that lead and copper concentration in treated water reaches below WHO drinking water norms $0.01 \mathrm{mg} / \mathrm{l}$ and $0.05 \mathrm{mg} / 1$, respectively.

\section{Conclusions}

In this study, simultaneous removal of lead and copper from synthetic wastewater through electrocoagulation was done in a batch reactor, it is found that the three factors (initial $\mathrm{pH}$, current density and treatment time) play an vital role for the removal of lead and copper, The optimum conditions for simultaneous removal of lead and copper are observed as; initial pH: 5, current density: $50 \mathrm{~A} / \mathrm{m}^{2}$ and treatment time: $40 \mathrm{~min}$. At these optimum conditions, removal of lead and copper are observed as $99.98 \%$ and $99.88 \%$, respectively with an operating cost of $0.476 \mathrm{USD} / \mathrm{m}^{3}$. Design Expert software is suitable for the prediction of lead and copper removal coupled with operating cost for electrocoagulation process. The treated water comes under WHO and Indian standard for drinking water as well as CPCB norms for discharge of heavy metal in environment with the initial lead and copper concentration of $10 \mathrm{mg} / \mathrm{l}$ and $40 \mathrm{mg} / \mathrm{l}$, respectively. 


\section{References}

Adhoum N., Monser L., Bellakhal N. and Belgaied J.E. 2004. Treatment of electroplating wastewater containing Cu2+, Zn2+ and $\mathrm{Cr}$ (VI) by electrocoagulation. Journal of Hazardous Materials, Vol. 112, pp. 207-213. https://doi.org/10.1016/j.jhazmat.2004.04.018

Bailey S.E., Olin T.J., Bricka R.M. and Adrian D.D. 1999. A review of potentially low-cost sorbents for heavy metals. Water Research, Vol. 33, pp. 2469-2479. https://doi.org/10.1016/S0043-1354(98)00475-8

Bazrafshan E., Mahvi A.H. and Zazouli M.A. 2011. Removal of zinc and copper from aqueous solutions by electrocoagulation technology using iron electrodes. Asian Journal of Chemistry, Vol. 23, pp. 5506.

Bhagawan D., Poodari S., Pothuraju T., Srinivasulu D., Shankaraiah G., Rani M.Y., Himabindu V. and Vidyavathi S. 2014. Effect of operational parameters on heavy metal removal by electrocoagulation. Environmental Science and Pollution Research, Vol. 21, pp.14166-14173. https://doi.org/10.1007/s11356-014-3331-8

Boujelben N., Bouzid J. and Elouear Z. 2009. Adsorption of nickel and copper onto natural iron oxide-coated sand from aqueous solutions: study in single and binary systems. Journal of Hazardous Materials, Vol. 163, pp. 376-382. https://doi.org/10.1016/j.jhazmat.2008.06.128.

Can O.T., Kobya M., Demirbas E. and Bayramoglu M. 2006. Treatment of the textile wastewater by combined electrocoagulation. Chemosphere, Vol. 62, pp. 181-187.

Ferreira S.C., Bruns R.E., Ferreira H.S., Matos G.D., David J.M., Brandao G.C., Silva E.P., Portugal L.A., Dos Reis P.S., Souza A.S. and Dos Santos W.N.L. 2007. Box-Behnken design: an alternative for the optimization of analytical methods. Analytica Chimica Acta, Vol. 597, pp. 179-186. https://doi.org/10.1016/j.aca.2007.07.011

Fu F. and Wang Q. 2011. Removal of heavy metal ions from wastewaters: a review. Journal of Environmental Management, vol. 92, pp. 407-418.

Gatsios E., Hahladakis J.N. and Gidarakos E. 2015. Optimization of electrocoagulation (EC) process for the purification of a real industrial wastewater from toxic metals. Journal of Environmental Management, Vol. 154, pp.117-127. https://doi.org/10.1016/j.jenvman.2015.02.018.

Ghernaout D. and Ghernaout B. 2012. Sweep flocculation as a second form of charge neutralization- A review. Desalination and Water Treatment, Vol. 44, pp. 15-28. https://doi.org/10.1080/19443994.2012.691699

Iqbal M. and Khera R.A. 2015. Adsorption of copper and lead in single and binary metal system onto Fumaria indica biomass. Chemistry International, vol. 1, pp. 157b-163b.

Kobya M., Can O.T., and Bayramoglu M. 2003. Treatment of textile wastewaters by electrocoagulation using iron and aluminum electrodes. Journal of Hazardous Materials, Vol. 100, pp. 163-178. https://doi.org/10.1016/S0304-3894(03)00102-X

Lakshmanan D., Clifford D.A. and Samanta G. 2009. Ferrous and ferric ion generation during iron electrocoagulation. Environmental Science \& Technology, Vol. 43, pp. 3853-3859. https://doi.org/10.1021/es8036669

Mansoorian H.J., Mahvi A.H. and Jafari A.J. 2014. Removal of lead and zinc from battery industry wastewater using Electrocoagulation process: Influence of direct and alternating current by using iron and stainless steel rod electrodes. Separation and Purification Technology, Vol. 135, pp. 165-175. https://doi.org/10.1016/j.seppur.2014.08.012

Mohod C.V. and Dhote J. 2013. Review of heavy metals in drinking water and their effect on human health. International Journal of Innovative Research in Science, Engineering and Technology, Vol. 2, pp. 2992-2996.

Rajput S., Pittman Jr C.U. and Mohan D. 2016. Magnetic magnetite (Fe3O4) nanoparticle synthesis and applications for lead $(\mathrm{Pb} 2+)$ and chromium (Cr6+) removal from water. Journal of Colloid and Interface Science, vol. 468, pp. 334-346. https://doi.org/10.1016/j.jcis.2015.12.008

Takeno N. 2005. Atlas of Eh-pH diagrams. Geological survey of Japan open file report, Vol. 419, pp.102.

Thakur L.S. and Mondal P. 2016. Techno-economic evaluation of simultaneous arsenic and fluoride removal from synthetic groundwater by electrocoagulation process: optimization through response surface methodology. Desalination and Water Treatment, Vol. 57, pp. 28847-28863. http://dx.doi.org/10.1080/19443994.2016.1186564

Thakur L.S., Goyal H. and Mondal P. 2019. Simultaneous removal of arsenic and fluoride from synthetic solution through continuous electrocoagulation: Operating cost and sludge utilization. Journal of Environmental Chemical Engineering, Vol. 7 , pp. 102829. https://doi.org/10.1016/j.jece.2018.102829

Web link 1 (Available at https://www.indiamart.com/proddetail/ms-sheet-13220081688.html, access date: 13/09/2018).

Web link 2

(Availableathttp://wss.mpcz.co.in/ShowProperty/UCMRepository/Contribution\%20Folders/Ujjain/PDF/MPERCRegulations/Ta rrif\%20order/Tariff_LT_HT_Year_17_18.pdf, accessdate: 13/09/2018)

Web link 3 Indian Standard water specification 1986 (Available at https://cpcb.nic.in/uploads/GeneralStandards.pdf access date: 10/09/2018).

Yetilmezsoy K., Demirel S. and Vanderbei R.J. 2009. Response surface modeling of Pb (II) removal from aqueous solution by Pistacia vera L.: Box-Behnken experimental design. Journal of Hazardous Materials, Vol. 171, pp. 551-562.

https://doi.org/10.1016/j.jhazmat.2009.06.035 


\section{Biographical notes}

A. K. Varma received M. Tech. and Ph.D. from Indian Institute of Technology Roorkee, India. He is working as an Assistant Professor in the Department of Chemical Engineering, Assam Energy Institute (A centre of RGIPT, Jais, Amethi) Sivasagar, Assam, INDIA.

A. Chouhan is doing his M.Tech. degree from Department of Chemical Engineering Ujjain Engineering College Ujjain, Madhya Pradesh, INDIA.

R. Shankar received M. Tech. and Ph.D. from Indian Institute of Technology Roorkee, India. He is working as an Assistant Professor in the Department of Chemical Engineering, Madan Mohan Malviya University of Technology, Gorakhpur, Uttar Pradesh, INDIA.

P. Mondal is a Professor in Department of Chemical Engineering, Indian Institute of Technology Roorkee, Roorkee, Uttarakhand, INDIA.

A.K. Rathore is an Associate Professor in the Department of Chemical Engineering, Harcourt Butler Technical University, Kanpur, Uttar Pradesh, INDIA.

L.S. Thakur is an Assistant Professor in the Department of Chemical Engineering Ujjain Engineering College Ujjain, Madhya Pradesh, INDIA. 